\title{
Enantioselective synthesis of the ester side chain of homoharringtonine
}

\author{
Vu T. Hue, Nguyen T H. Nhung, and Mac D. Hung* \\ Medicinal Chemistry Laboratory, VNU-University of Science \\ 19 Le Thanh Tong, Hanoi, Viet Nam \\ E-mail: macdinhhung@,vnu.edu.vn
}

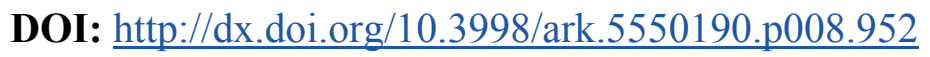

\begin{abstract}
From D-Malic acid as chiral starting material, an efficient synthesis of the ester side chain of homoharringtonine has been developed. A cross-metathesis reaction leads to the formation of the key intermediate, which can be converted later by selective hydrogenation to the methyl ester side chain of homoharringtonine and deoxy-homoharringtoine in a total of six steps with $24.5 \%$ and $23.5 \%$ in yields, respectively.
\end{abstract}

Keywords: Homoharringtonine, cross-metathesis, cephalotaxine, self-retention of chirality

\section{Introduction}

Homoharringtonine (HHT) has been proved to be the most potent member of the cephalotaxus esters in treating leukemia. ${ }^{1-3}$ Research on the biological properties of this alkaloid has shown that HHT inhibits protein biosynthesis in the cell via the breakdown of polyribosomes, the release of completed globin chain, and the inhibition of the initiation of protein synthesis without effecting chain elongation. ${ }^{4-5}$ In 2012, omacetaxine mepesuccinate (Synribo), a semisynthetic HHT compound (99.7\% purity) was used in studies of chronic myeloid leukemia (CML) and approved by the FDA for the treatment of CML. Later approval from the FDA in 2013 for this drug to be self-administered by patients further demonstrated its efficacy and safety. ${ }^{6}$

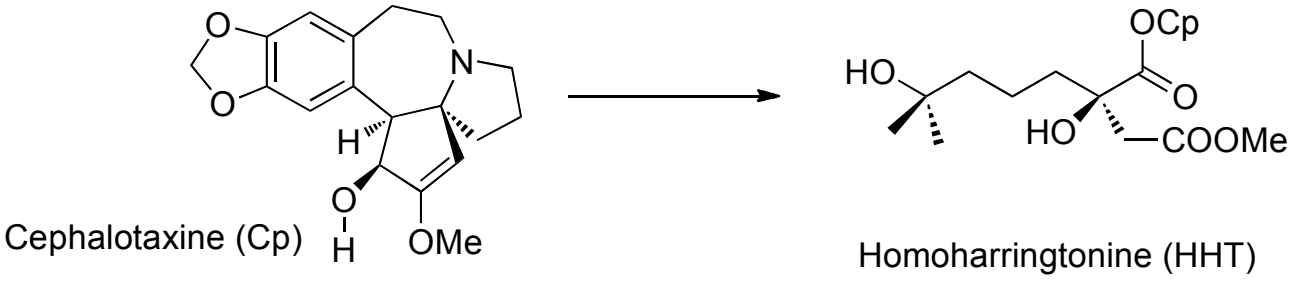

Figure 1. Cephalotaxine and Homoharringtonine. 
Limited availability of HHT together with the higher purity of semisynthetic HHT over natural sources have engendered much interest in the semisynthesis of HHT from the more abundant but biologically inactive cephalotaxine. A number of synthetic approaches to the ester side chain of HHT have been described. ${ }^{7-10}$ In 2001, Jean d'Angelo and co-workers reported a ten-step stereoselective approach to the methyl ester derivative of the HHT side chain via a regio- and stereoselective Michael addition on a chiral amine. ${ }^{11}$ Starting from a chiral citric acid derivative, Russell described an approach to HHT ester side chain acid via Rosenmund reduction of homocitrate to form the corresponding aldehyde. ${ }^{12}$ This aldehyde was then oxidized to form Robin's acid, which could be attached to the cephalotaxine moiety via Robin's first semisynthesis of HHT. ${ }^{13}$ More recently, Yang reported the [2,3]-Meisenheimer rearrangement in the construction of chiral tertiary alcohols in the ester side chain. ${ }^{14}$ However, there is still a need for a better and more convenient synthesis of the side chain in order to perform an efficient transformation from cephalotaxine to homoharringtonine.

Herein we reported a synthetic approach to the ester side chain that is enantioselective, convenient, and distinct from the previous methods. The strategy is based on the Seebach's procedure of alkylation of D-Malic acid with "self-retention of chirality" and the cross metathesis reaction of the resulted allyl acid with a tertiary alkenyl alcohol. The success of this synthetic approach enables an efficient pathway to HHT side chain synthesis as well as to that of other Cephalotaxus side chain ester derivatives.

\section{Results and Discussion}

Our methodology started with the application of Seebach's concept of "self-reproduction of chirality" as a means to introduce the stereocenter of the ester side chain. Starting with D-Malic acid as a readily available chiral starting material, dioxolanone $\mathbf{2}$ was synthesized as previously reported. ${ }^{15}$ The cis-product was predominant due to its being favored thermodynamically.
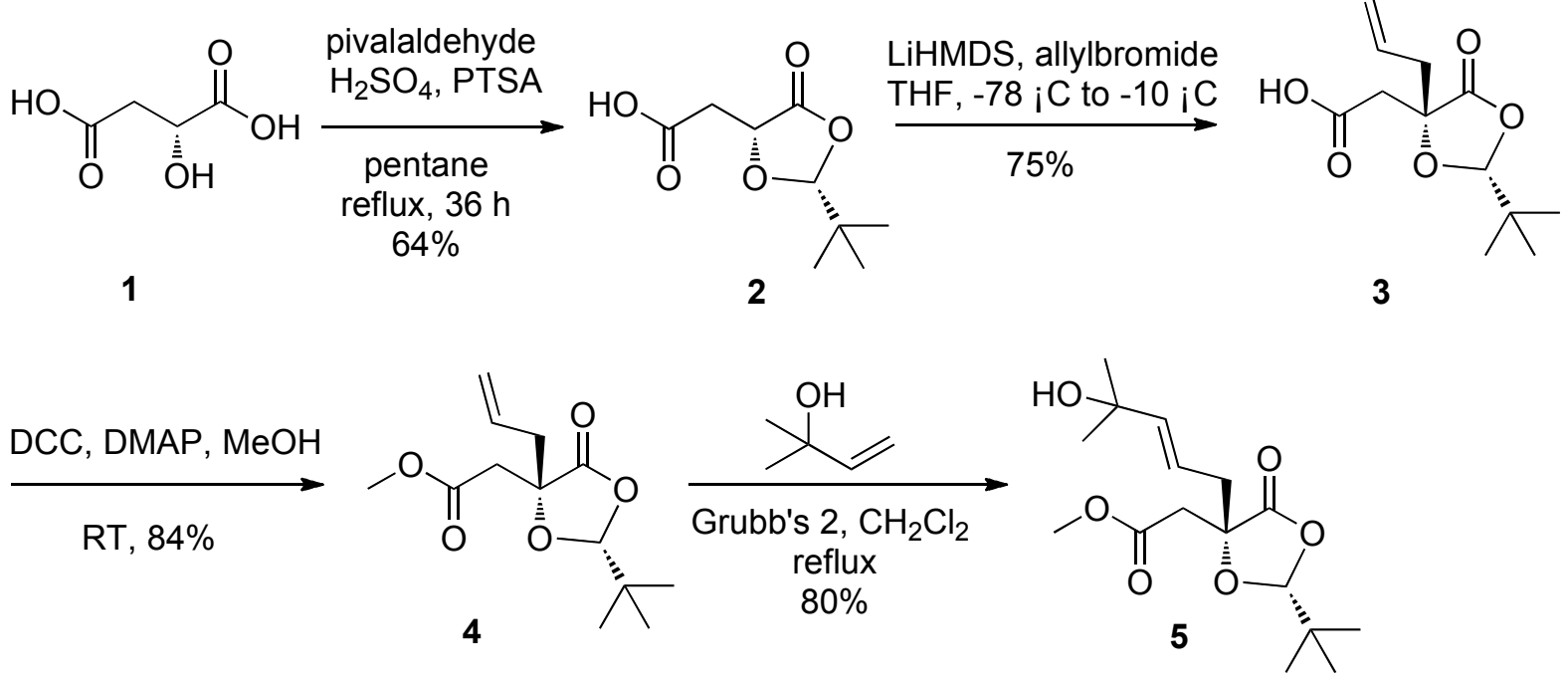

Scheme 1. Synthesis of the key intermediate 5. 
The allylation of the dioxolanone 2 with allyl bromide in the presence of two equivalents of LiHMDS in THF at $-78{ }^{\circ} \mathrm{C}$ gave the desired compound in $75 \%$ yield. Due to the strong steric hinderance by the $t$-butyl group, the allyl electrophile attacks from the opposite face, thereby securing the required $R$-configuration.

The cross metathesis of the acid 3 with 2-methylbut-3-en-2-ol was next undertaken using Grubbs's 2 catalyst $^{16}$ in DCM with a large excess of the tertiary alcohol. Unfortunately, only starting materials together with the dimerization product of the alcohol were observed. However, the transformation of acid 3 into its methyl ester 4 by DCC/DMAP ${ }^{17}$ in the presence of catalytic amount of PTSA, permitted the cross metathesis to succeed in high yield. ${ }^{1} \mathrm{H}$ NMR analysis showed that the product $\mathbf{5}$ exists mainly as the trans-isomer.

With the key intermediate 5 in hand, hydrogenation of the double bond with $\mathrm{H}_{2}-\mathrm{Pd} / \mathrm{C}$ in methanol gave surprisingly a quantitative dehydroxy product 7 . This result can be explained by the fact that the allylic alcohol position in $\mathbf{5}$ is slightly acidic, thus making it more favourable to be removed under the reaction conditions. Addition of an amine, to neutralize the alcohol and afford a selective hydrogenation, was then applied. After several trials, we found that one equivalent of triethylamine in ethanol permitted a complete conversion of $\mathbf{5}$ into the desired product 6. The final transformations of the protected dioxalanes $\mathbf{6}$ and $\mathbf{7}$ were performed smoothly using $\mathrm{MeOH} / \mathrm{MeONa}$ affording the methyl ester side chains of homoharringtonine 8 and deoxy-homoharringtonine $\mathbf{9}$ in very high yields. The NMR and optical rotation data obtained were identical with the reported data. ${ }^{18}$

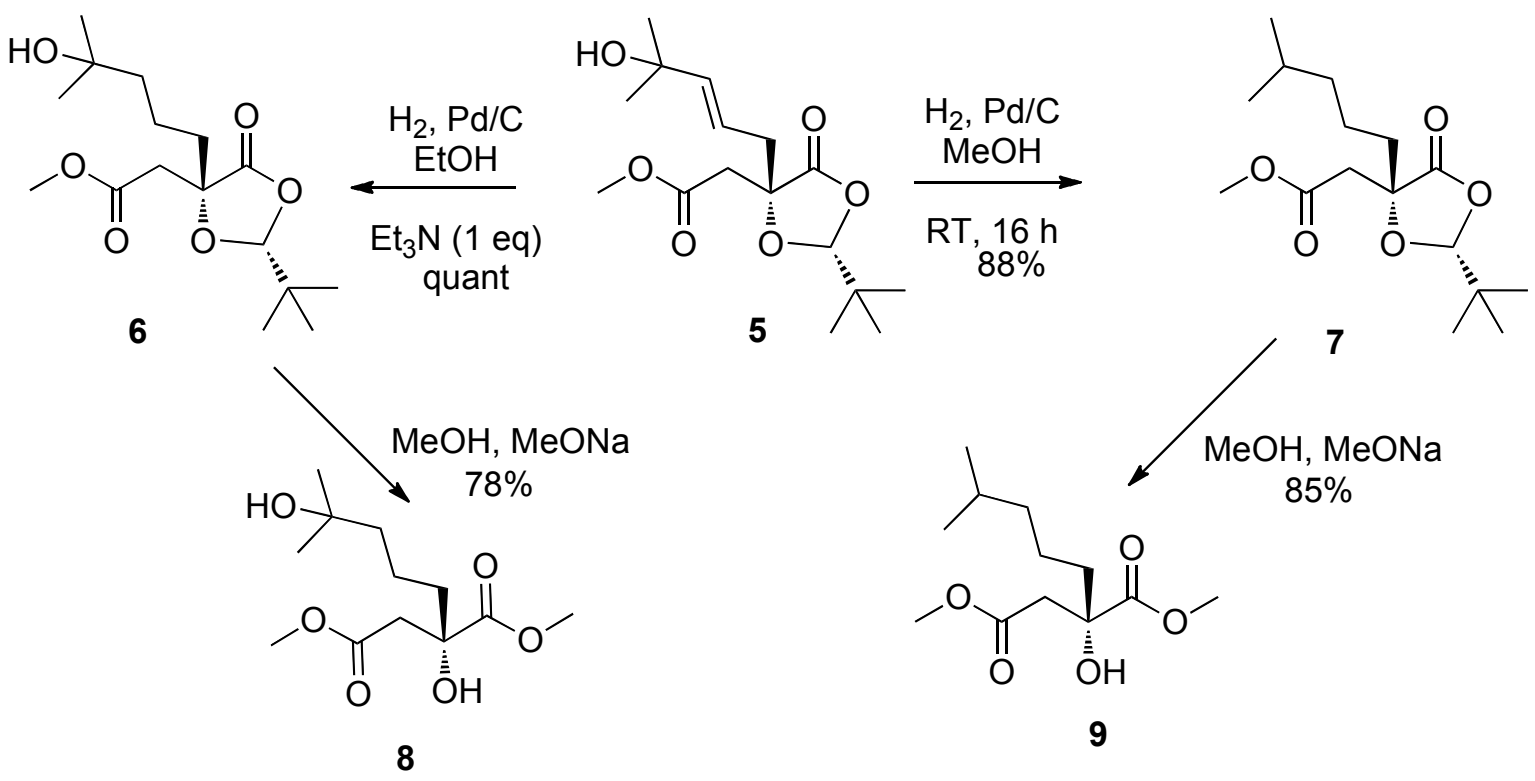

Scheme 2. Synthesis of the methyl ester side chains. 


\section{Conclusions}

An enantioselective synthesis of homoharringtonine ester side chain and its deoxy-derivative have been completed in six steps with $24.5 \%$ and $23.5 \%$ overall yields, respectively. The key tactical elements of this synthesis include the use of chiral malic acid as starting material and the cross metathesis with available methylbut-3-en-2-ol. These enabled an efficient access to the protected intermediate $\mathbf{5}$, which can be converted easily into methyl ester of the side chain. This strategy can be considered as a potential pathway to the semi-synthesis of homoharringtonine and its derivatives by the coupling of cephalotaxine and the ester side chain. Studies directed towards the esterification of the $\alpha$-hydroxy acid with cephalotaxin to produce enantiopure HHT are currently under investigation.

\section{Experimental Section}

General. All the reactions were carried out under a nitrogen atmosphere. Unless otherwise noted, all the reagents obtained from commercial sources were used without further purification. All solvents were dried by standard methods. THF were dried with sodium and benzophenone and used immediately after distillation. DCM was dried with diphosphorus pentoxide $\left(\mathrm{P}_{2} \mathrm{O}_{5}\right)$. Pentane was distilled and then dried with sodium. Analytical thin-layer chromatography (TLC) was performed on $0.25 \mathrm{~mm}$ Merck precoated silica gel plates (60-F254). Column chromatography was carried out with silica gel (60-F254). The TLC plates were visualized with a UV lamp (254 $\mathrm{nm}$ and $366 \mathrm{~nm}$ ) and/or with TLC visualizing solutions activated with heat, including: $p$-anisaldehyde solution and potassium permanganate solution. Mass spectral analyses were performed with a VARIAN 920-MS at VAST. The specific optical rotation data were measured with a JASCO P-2000 Polarimeter instrument (wavelength of the light used was $589 \mathrm{~nm}$ ). ${ }^{1} \mathrm{H}$ NMR and ${ }^{13} \mathrm{C}$ NMR were recorded on BRUKER 300 and $500 \mathrm{MHz}$ instruments using TMS as the internal standard and $\mathrm{CDCl}_{3}$ as the solvent.

2-((2R, 4R)-2-tert-Butyl-5-oxo-1,3-dioxolan-4-yl)acetic acid (2). To a suspension of D-(+)malic acid $(10 \mathrm{~g}, 74.58 \mathrm{mmol})$ and pivalaldehyde $(13.2 \mathrm{~mL}, 116.1 \mathrm{mmol})$ in pentane $(150 \mathrm{~mL})$, PTSA (1.1 g, $6.39 \mathrm{mmol})$ and concentrated $\mathrm{H}_{2} \mathrm{SO}_{4}$ (2 drops) were added. The mixture was heated under reflux for $40 \mathrm{~h}$ with azeotropic removal of water. The resulting suspension was filtered. The solid cake was dissolved in $\mathrm{CH}_{2} \mathrm{Cl}_{2}$, and washed with $8 \%$ aqueous $\mathrm{H}_{3} \mathrm{PO}_{4}(2 \times 40 \mathrm{~mL})$. The combined organic phases were dried with $\mathrm{Na}_{2} \mathrm{SO}_{4}$. The solvent was removed under vacuum, giving $9.554 \mathrm{~g}$ of the product as a white solid (yield 64\%). $[\alpha]_{\mathrm{D}}{ }^{24}+2.20(c 1.00, \mathrm{MeOH}) .{ }^{1} \mathrm{H}$ NMR $\left(300 \mathrm{MHz}, \mathrm{CDCl}_{3}\right): \delta_{\mathrm{H}} 5.33(\mathrm{~m}, 1 \mathrm{H}), 4.77-4.54(\mathrm{~m}, 1 \mathrm{H}), 3.08-2.77(\mathrm{~m}, 2 \mathrm{H}), 0.98(\mathrm{~s}$, $9 \mathrm{H}) .{ }^{13} \mathrm{C}$ NMR $\left(75 \mathrm{MHz}, \mathrm{CDCl}_{3}\right): \delta_{\mathrm{c}} 1745.0,172.4,111.4,71.4,35.9,35.4,23.4$.

2-((2R,4R)-2-tert-butyl-4-allyl-5-oxo-1,3-dioxolan-4-yl)acetc acid (3). To a stirred solution of dioxolanone $2(1.78 \mathrm{~g}, 8.83 \mathrm{mmol})$ in THF $(110 \mathrm{~mL})$ a solution of LiHMDS $(0.5 \mathrm{M}$ in THF, 
$17.65 \mathrm{~mL}, 8.83 \mathrm{mmol}, 1$ eq.) was slowly added at $-78{ }^{\circ} \mathrm{C}$ through a dropping funnel. After 15 min, another portion of $17.65 \mathrm{~mL}$ LiHMDS $0.5 \mathrm{M}$ in THF (1 eq.) was added slowly to the mixture and it was stirred for $20 \mathrm{~min}$. After the dropwise addition of the allyl bromide $(1.53 \mathrm{~mL}$, $17.65 \mathrm{mmol}, 2 \mathrm{eq}$ ) over a period of $20 \mathrm{~min}$ the temperature was raised up to $-10{ }^{\circ} \mathrm{C}$ over a period of $5.5 \mathrm{~h}$. The resulting solution was partitioned between EtOAc and $1 \mathrm{M} \mathrm{HCl}$, and extracted with EtOAc. The combined organic phases were dried with $\mathrm{Na}_{2} \mathrm{SO}_{4}$. The solvent was removed under vacuum and the residue purified by column chromatography (hexane/EtOAc, 9:1 - 1:1) to give $1.67 \mathrm{~g}$ pure product as yellow oil, yield $75 \%$. $\quad \mathrm{R}_{\mathrm{f}} 0.2$ (hexane/EtOAc, $\left.4: 1\right)$. $[\alpha]_{\mathrm{D}}{ }^{24}-18(c 1.1$, $\mathrm{MeOH}) .{ }^{1} \mathrm{H}$ NMR $\left(300 \mathrm{MHz}, \mathrm{CDCl}_{3}\right): \delta_{\mathrm{H}} 5.90-5.73(\mathrm{~m}, 1 \mathrm{H}), 5.32-5.18(\mathrm{~m}, 3 \mathrm{H}), 2.85(\mathrm{~d}, J 1.8$ $\mathrm{Hz}, 2 \mathrm{H}), 2.57(\mathrm{~m}, J=7.6,5.1,1.1 \mathrm{~Hz}, 2 \mathrm{H}), 0.95(\mathrm{~s}, 9 \mathrm{H}) .{ }^{13} \mathrm{C} \mathrm{NMR}\left(75 \mathrm{MHz}, \mathrm{CDCl}_{3}\right): \delta_{\mathrm{c}} 173.5$, 173.4, 130.0, 121.3, 108.5, 79.8, 39.4, 38.16, 34.4, 23.6.

Methyl 2-((2R,4R)-2-tert-butyl-4-allyl-5-oxo-1,3-dioxolan-4-yl)acetate (4). To a solution of acid 3 (158 mg, $0.654 \mathrm{mmol})$ in $3.5 \mathrm{~mL}$ of MeOH (86.5 mmol, $132 \mathrm{eq})$ was added DMAP (6 mg, $0.0491 \mathrm{mmol}, 7.5 \mathrm{~mol} \%)$ and $p$-TsOH $(5.7 \mathrm{mg}, 0.03 \mathrm{mmol}, 4.6 \mathrm{~mol} \%)$. The mixture was cooled to $0{ }^{\circ} \mathrm{C}$, then, DCC (170 mg, $0.824 \mathrm{mmol}, 1.26$ eq.) was added. After $18 \mathrm{~h}$, the reaction was diluted with $20 \mathrm{~mL} \mathrm{MeOH}$. The solution was filtered through Celite and the solvent was removed in vacuum. The product was purified by column chromatography (hexane: EtOAc 9:1 $6: 1$ ) to give $137 \mathrm{mg}$ ester as a colorless oil, yield $84 \%$. $\mathrm{R}_{\mathrm{f}} 0.5$ (hexane/EtOAc, 4:1). $[\alpha]_{\mathrm{D}}{ }^{24}-14(c$ 0.5, MeOH). ${ }^{1} \mathrm{H}$ NMR $\left(500 \mathrm{MHz}, \mathrm{CDCl}_{3}\right): \delta_{\mathrm{H}} 5.82(\mathrm{~m}, J 7.2,9.7,17.6 \mathrm{~Hz}, 1 \mathrm{H}), 5.26-5.20(\mathrm{~m}$, $3 \mathrm{H}), 3.66(\mathrm{~s}, 3 \mathrm{H}), 2.82(\mathrm{dd}, J 1.3,12.1 \mathrm{~Hz}, 2 \mathrm{H}), 2.62-2.52(\mathrm{~m}, 2 \mathrm{H}), 0.94(\mathrm{~s}, 9 \mathrm{H}) .{ }^{13} \mathrm{C} \mathrm{NMR}(125$ $\left.\mathrm{MHz}, \mathrm{CDCl}_{3}\right): \delta_{\mathrm{c}} 173.5,168.7,130.1,121.1,108.7,79.9,51.9,39.7,38.2,34.2,23.5$. HRMS $\mathrm{m} / z$ calculated for $[\mathrm{M}+\mathrm{Na}]^{+} \mathrm{C}_{13} \mathrm{H}_{20} \mathrm{NaO}_{5} 279.1208$ found 279.1201 .

Cross-metathesis product of ester with 2-methyl-but-3-en-2-ol (5). Ester 4 (27 mg, 0.105 $\mathrm{mmol})$ and Grubbs II catalyst $(8 \mathrm{mg}, 0.005 \mathrm{mmol})$ were dissolved in $1 \mathrm{~mL}$ of 2-methyl-but-3-en2-ol (90 eq.). The mixture was refluxed at $45{ }^{\circ} \mathrm{C}$ for $18 \mathrm{~h}$. The solvent was then removed and the product was purified by column chromatography (hexane: EtOAc 4:1 - 2:1) to give $30 \mathrm{mg}$ of the product 5 (26 mg, 80\% yield). $\mathrm{R}_{\mathrm{f}} 0.5$ (hexane/ EtOAc, $\left.1: 1\right) .{ }^{1} \mathrm{H} \mathrm{NMR}\left(500 \mathrm{MHz}, \mathrm{CDCl}_{3}\right): \delta_{\mathrm{H}} 5.78$ $(\mathrm{d}, J 15.5 \mathrm{~Hz}, 1 \mathrm{H}), 5.60(\mathrm{~m}, J=15.5,7.4 \mathrm{~Hz}, 1 \mathrm{H}), 5.18(\mathrm{~s}, 1 \mathrm{H}), 3.65(\mathrm{~s}, 3 \mathrm{H}), 2.79$ (dd, $J 15.5$, 9.5Hz, 2H), $2.52(\mathrm{~m}, 2 \mathrm{H}), 2.02(\mathrm{~m}, 2 \mathrm{H}), 1.30(\mathrm{~s}, 6 \mathrm{H}), 0.94(\mathrm{~s}, 9 \mathrm{H}) .{ }^{13} \mathrm{C} \mathrm{NMR}\left(125 \mathrm{MHz}, \mathrm{CDCl}_{3}\right)$ : $\delta_{\mathrm{c}} 173.5,168.7,146.0,144.5,118.2,110.8,108.3,80.1,70.5,51.9,39.7,36.7,34.2,29.6,29.6$, 29.3, 23.5. HRMS $m / z$ calculated for $[\mathrm{M}+\mathrm{Na}]^{+} \mathrm{C}_{16} \mathrm{H}_{26} \mathrm{NaO}_{6} 337.1627$ found 337.1620.

Methyl 2-((2R, 4R)-2-tert-butyl-4- (4-hydroxy-4-methylpentyl)-5-oxo-1,3-dioxolan-4-yl)acetate (6). $46 \mathrm{mg}$ of $5(0.147 \mathrm{mmol})$ was dissolved in $3 \mathrm{~mL}$ of EtOH. $7.5 \mathrm{mg}$ of $\mathrm{Pd} / \mathrm{C}(17 \%$ weight) and $25 \mu \mathrm{L}$ of TEA ( 1 eq) were added. The solution was then bubbled with $\mathrm{H}_{2}$ in 15 min and keeps stirring in $\mathrm{H}_{2}$ atmosphere for 3 hours. The solvent was then evaporated and the product was purified by column chromatography (hexane: EtOAC 4:1) to give $48 \mathrm{mg}$ of 6 (yield 100\%). $[\alpha]_{\mathrm{D}}{ }^{24}-26.4\left(c\right.$ 0.5, MeOH). $\mathrm{R}_{\mathrm{f}} 0.15$ (Hexane/EtOAc, 4:1). ${ }^{1} \mathrm{H}$ NMR $\left(500 \mathrm{MHz}, \mathrm{CDCl}_{3}\right): \delta_{\mathrm{H}} 5.15$ $(\mathrm{s}, 1 \mathrm{H}), 3.65(\mathrm{~s}, 3 \mathrm{H}), 2.81(\mathrm{~s}, 2 \mathrm{H}), 1.44-1.80(\mathrm{~m}, 7 \mathrm{H}), 1.44(\mathrm{~s}, 6 \mathrm{H}), 0.93(\mathrm{~s}, 9 \mathrm{H}) .{ }^{13} \mathrm{C}$ NMR $(125$ $\left.\mathrm{MHz}, \mathrm{CDCl}_{3}\right): \delta_{\mathrm{c}} 174.5,169.3,108.9,80.8,71.2,52.6,44.1,40.3,34.9,34.9,29.9,29.9,24.2$, 18.8. . HRMS $m / z$ calculated for $[\mathrm{M}+\mathrm{Na}]^{+} \mathrm{C}_{16} \mathrm{H}_{28} \mathrm{NaO}_{6} 339.1784$ found 339.1776 . 
Methyl 2-((2R,4R)-2-tert-butyl-4-(4-methylpentyl)-5-oxo-1,3-dioxolan-4-yl)acetate (7). 50 $\mathrm{mg}$ of $5(0.159 \mathrm{mmol})$ was dissolved in $5 \mathrm{~mL}$ of MeOH. $7 \mathrm{mg}$ of $\mathrm{Pd} / \mathrm{C}$ (14\% weight) was added. The solution was then bubbled with $\mathrm{H}_{2}$ in $15 \mathrm{~min}$ and keeps stirring in $\mathrm{H}_{2}$ atmosphere for 3 hours. The solvent was then evaporated and the product was purified by column chromatography (Hexane: EtOAC 5:1) to give $44 \mathrm{mg}$ of $7(88 \%)$. $\mathrm{R}_{\mathrm{f}} 0.65$ (hexane/ EtOAc, 4:1). $[\alpha]_{\mathrm{D}}{ }^{24}-20.1(c$ 0.4, MeOH). $\quad \mathrm{R}_{\mathrm{f}} 0.65$ (Hexane/ EtOAc, 4:1). ${ }^{1} \mathrm{H}$ NMR $\left(500 \mathrm{MHz}, \mathrm{CDCl}_{3}\right): \delta_{\mathrm{H}} 5.16(\mathrm{~s}, 1 \mathrm{H}), 3.67$ $(\mathrm{s}, 3 \mathrm{H}), 2.83(\mathrm{~s}, 2 \mathrm{H}), 1.78(\mathrm{~m}, 1 \mathrm{H}), 1.25(\mathrm{~m}, 4 \mathrm{H}), 1.20(\mathrm{~m}, 2 \mathrm{H}), 0.95(\mathrm{~s}, 9 \mathrm{H}), 0.86(\mathrm{~d}, J 6.6 \mathrm{~Hz}$, $6 \mathrm{H}) .{ }^{13} \mathrm{C}$ NMR $\left(125 \mathrm{MHz}, \mathrm{CDCl}_{3}\right): \delta_{\mathrm{c}} 174.2,169.0,108.4,80.5,52.1,39.9,39.0,34.5,34.2$, 29.9, 27.9, 23.8, 22.6, 22.6, 21.3. HRMS $m / z$ calculated for $[\mathrm{M}+\mathrm{Na}]^{+} \mathrm{C}_{16} \mathrm{H}_{28} \mathrm{NaO}_{5} 323.1834$ found 323.1831 .

General synthetic procedure, exemplified by $(R)$-dimethyl 2-hydroxy-2-(4-hydroxy-4methylpentyl)succinate (8). $9.5 \mathrm{mg}$ of 6 was dissolved in $1 \mathrm{~mL}$ of $\mathrm{MeOH}$ (previously dried and distilled with sodium). Next, $40 \mu \mathrm{L}$ of $\mathrm{NaOMe} 1 \mathrm{M}$ (1.2 eq) was aded. The reaction mixture was stirred for $1 \mathrm{~h}$ for a complete conversion. The solvent was then evaporated. The residue was dissolved in EtOAc and washed with $\mathrm{HCl} 0.1 \mathrm{~N}$. The organic layer was dried by $\mathrm{Na}_{2} \mathrm{SO}_{4}$, filtered, evaporated under vacuum. The crude was purified by flash chromatography on silica gel to give desired product. $[\alpha]_{\mathrm{D}}{ }^{24}-15(c 0.2, \mathrm{MeOH}) ; \mathrm{R}_{\mathrm{f}} 0.2$ (hexane/EtOAc, 4:1).

(R)-dimethyl 2-hydroxy-2-(4-hydroxy-4-methylpentyl)succinate (8) ${ }^{1} \mathrm{H}$ NMR $(500 \mathrm{MHz}$, $\left.\mathrm{CDCl}_{3}\right): \delta_{\mathrm{H}} 3.80(\mathrm{~s}, 3 \mathrm{H}), 3.67(\mathrm{~s}, 3 \mathrm{H}), 2.93(\mathrm{~d}, J 16.2 \mathrm{~Hz}, 1 \mathrm{H}), 2.68(\mathrm{~d}, J 16.2 \mathrm{~Hz}, 1 \mathrm{H}), 1.81-1.83$ $(\mathrm{m}, 2 \mathrm{H}), 1.54-1.60(\mathrm{~m}, 2 \mathrm{H}), 1.45-1.49(\mathrm{~m}, 2 \mathrm{H}), 1.22(\mathrm{~s}, 6 \mathrm{H}) .{ }^{13} \mathrm{C} \mathrm{NMR}\left(125 \mathrm{MHz}, \mathrm{CDCl}_{3}\right): \delta_{\mathrm{c}}$ $175.6,171.3,75.2,70.8,52.9,51.9,43.5,43.4,39.6,29.4,29.1,18.1$. HRMS $m / z$ calculated for $[\mathrm{M}+\mathrm{Na}]+\mathrm{C}_{12} \mathrm{H}_{22} \mathrm{NaO}_{6} 285.1314$ found 285.1319 .

(R)-dimethyl 2-hydroxy-2-(4-methylpentyl)succinate (9). Following the general procedure above, 9 was obtained in $85 \%$ yield. $[\alpha]_{\mathrm{D}}{ }^{24}-16.7(c 0.3, \mathrm{MeOH}) . \quad \mathrm{R}_{\mathrm{f}} 0.45$ (hexane/EtOAc, 4:1). ${ }^{1} \mathrm{H}$ NMR $\left(500 \mathrm{MHz}, \mathrm{CDCl}_{3}\right): \delta_{\mathrm{H}} 3.80(\mathrm{~s}, 3 \mathrm{H}), 3.67(\mathrm{~s}, 3 \mathrm{H}), 2.93(\mathrm{~d}, J 16.2 \mathrm{~Hz}, 1 \mathrm{H}), 2.68(\mathrm{~d}, J$ $16.2 \mathrm{~Hz}, 1 \mathrm{H}), 1.43-1.66(\mathrm{~m}, 5 \mathrm{H}), 1.131 .15(\mathrm{~m}, 2 \mathrm{H}), 0.84(\mathrm{~d}, J 6.6 \mathrm{~Hz}, 6 \mathrm{H}) .{ }^{13} \mathrm{C} \mathrm{NMR}(125$ $\left.\mathrm{MHz}, \mathrm{CDCl}_{3}\right): \delta_{\mathrm{c}} 175.7,171.4,75.3,52.9,51.9,43.4,39.5,38.8,27.8,22.6,22.5,20.1 . \mathrm{HRMS}$ $m / z$ calculated for $[\mathrm{M}+\mathrm{Na}]+\mathrm{C}_{12} \mathrm{H}_{22} \mathrm{NaO}_{5} 269.1365$ found 269.1360

\section{Acknowledgements}

We thank VNU-HUS (QG.12-07) for support of this research.

\section{References}

1. Ma, G.; Palmer, D. R. J. Tetrahedron Lett. 2000, 41, 9209.

http://dx.doi.org/10.1016/S0040-4039(00)01707-X 
2. Powell, R. G.; Weisleder, D.; Smith Jr, C. R.; Rohwedder, W. K. Tetrahedron Lett. 1970, $11,815$. http://dx.doi.org/10.1016/S0040-4039(01)97839-6

3. Jalil Miah, M. A.; Hudlicky, T.; Reed, J. W.; Geoffrey, A. C., Chapter 2 Cephalotaxus Alkaloids. In The Alkaloids: Chemistry and Biology, Academic Press: 1998, 51, 199.

4. Mikolajczak, K. L.; Powell, R. G.; Smith Jr, C. R. Tetrahedron. 1972, 28, 1995. http://dx.doi.org/10.1016/0040-4020(72)88007-4

5. Abdelkafi, H.; Nay B. Nat.Prod.Rep. 2012, 29, 845. http://dx.doi.org/10.1039/C2NP20037F

6. Kantarjian, H. M.; O’Brien, S.; Cortes, J. Clinical Lymphoma, Myeloma and Leukemia. 2013, 13,530 . http://dx.doi.org/10.1016/j.clml.2013.03.017

7. Hiranuma, S.; Shibata, M.; Hudlicky, T. J. Org. Chem. 1983, 48, 5321. http://dx.doi.org/10.1021/jo00174a031

8. Hiranuma, S; Hudlicky, T. Tetrahedron Lett. 1982, 23, 3431. http://dx.doi.org/10.1016/S0040-4039(00)87634-0

9. Eckelbarger, J. D.; Wilmot, J. T.; Epperson, M. T.; Thakur, C. S.; Shum, D.; Antczak, C.; Tarassishin, L.; Djaballah, H.; Gin, D. Y. Chem. Eur. J. 2008, 14, 4293. http://dx.doi.org/10.1002/chem.200701998

10. Keller, L.; Dumas, F.; d'Angelo, J. Eur. J. Org. Chem. 2003, 2488. http://dx.doi.org/10.1002/ejoc.200300111

11. Keller, L.; Dumas, F.; d'Angelo, J. Tetrahedron Lett. 2001, 42, 1911. http://dx.doi.org/10.1016/S0040-4039(01)00086-7

12. Rachael A. A.; Andrew T. R.; Adam J. S. Chem. Commun. 2006, 3243. http://dx.doi.org/10.1039/B605339D

13. Robin, J.-P.; Dhal, R.; Dujardin, G.; Girodier, L.; Mevellec, L.; Poutot, S. Tetrahedron Lett. 1999, 40, 2931. http://dx.doi.org/10.1016/S0040-4039(99)00327-5

14. Hua, Y.; Moran, S , Shuguang, Z.; Ming, Z.; Yangla, X.; Changling, N.; Chunlin, L. J. Org. Chem. 2013, 78, 339. http://dx.doi.org/10.1021/jo302203g

15. Seebach, D.; Naef, R.; Calderari, G. Tetrahedron 1984, 40, 1313. http://dx.doi.org/10.1016/S0040-4020(01)82417-0

16. Chatterjee, A. K.; Choi, T.-L.; Sanders, D. P.; Grubbs, R. H. J. Am. Chem. Soc. 2003, 125, 11360. http://dx.doi.org/10.1021/ja0214882

17. Neises, B.; Steglich, W. Angew. Chem., Int. Ed. Eng. 1978, 17, 522. http://dx.doi.org/10.1002/anie.197805221

18. Powell, R. G.; Weisleder, D.; Smith Jr, C. R. J. Pharm. Sci. 1972, 61, 1227. http://dx.doi.org/10.1002/jps.2600610812 